ФОРМУВАННЯ ІНФОРМАЦІЙНО-КОМУНІКАТИВНОЇ

КОМПЕТЕНТНОСТІ СТУДЕНТІВ ТЕХНІЧНИХ СПЕЦІАЛЬНОСТЕЙ

НА ЗАНЯТТЯХ 3 АНГЛІЙСЬКОї МОВИ

\title{
FORMATION OF INFORMATION AND COMMUNICATIVE COMPETENCE OF STUDENTS OF TECHNICAL SPECIALTIES IN THE ENGLISH LANGUAGE CLASSES
}

УДК 378:661.041

DOI https://doi.org/10.32843/2663-

6085/2021/31-1.33

\section{Саєнко Н.С.,}

канд. пед. наук, професор, декан фракультету лінгвістики Національного технічного університету України «Київський політехнічний інститут імені Ігоря Сікорського»

\section{Галацин К.О.,}

канд. пед. наук,

доцент кафедри англійської мови технічного спрямування

Національного технічного університету України «Київський політехнічний інститут імені Ігоря Сікорського»
Актуальність проблеми фрормування інфрормаційно-комунікативної компетентності зумовлена тим, що сучасне інфрормаційне суспільство потребує підготовки фрахівця, здатного до організації різнобічних ділових контактів із використанням різних інсрормачійних технологій. Тому стаття присвячена аналізу теорії та практики фрормування інфоормаційно-комунікативної компетентності майбутніх інженерів машинобудівної сорери у прочесі вивчення англійської мови. мета статті полягає в обірунтуванні теорії та практики формування інфоораційнокомунікативної компетентності майбутніх інженерів на заняттях з англійської мови у закладах вищої технічної освіти. Реалізація мети потребує вирішення таких завдань: 1) визначити сутність інсрормаційної, комунікативної та інфрормаційно-комунікативної компетентності майбутніх інженерів; 2) проаналізувати теорію й практику фоормування інсоормаційно-комунікативної компетентності майбутніх інженерів на заняттях з англійської мови.

У процесі виконання завдань використано методи аналізу, синтезу, узагальнення, систематизації, вивчення нормативних документів.

Інсрормаційно-комунікативну компетентність майбутнього інженера будемо розуміти як інтегральну характеристику особистості, яка полягає у сформованій здатності налагоджувати та здійснювати професійну комунікативну взаємодію з використанням вербальних та невербальних засобів комунікації, інсрормаційно-комунікаційних технологій задля вирішення профресійних завдань у технічній сфрері та задля особистісного і профресійного вдосконалення.

Розглянуто та проаналізовано досвід власної практичної діяльності на заняттях англійської мови з використанням завдань, спрямованих на формування в майбутніх інженерів машинобудівної галузі інформаційно-комунікативної компетентності.

Ключові слова: компетентність, інформаційна компетентність, комунікативні компетентність, майбутні інженери, заняття з англійської мови в закладах вищої технічної освіти, формування компетентностей.

The relevance of the problem of formation information and communicative competence is due to the fact that modern information society requires the training of a specialist capable of organizing versatile business contacts using various information technologies. Therefore, the article is devoted to the analysis of the theory and practice of formation the information and communicative competence of future mechanical engineers in the process of studying English.

The purpose of the article is to substantiate the theory and practice of formation the information and communication competence of future engineers in English language classes at higher technical education institutions. The realization of the goal requires solving the following problems: 1) to determine the essence of the information, communicative and information and communicative competence of future engineers 2) analyse the theory and practice of formation information and communicative competence of future engineers in English language classes. In the process of performing tasks, methods of analysis, synthesis, generalization, systematization, study of normative documents were used.

The information and communication competence of the future engineer will be understood as an integral characteristic of the personality, which consists in the established ability to perform and carry out professional communication using verbal and non-verbal means of communication, information and communication technologies to solve professional tasks in the technical field and for personal and professional improvement.

We considered and analysed the experience of our own practical activities in English language classes on the use of tasks aimed at creating information and communicative competence among future engineers of the mechanical engineering industry.

Key words: competence, information competence, communicative competence, future engineers, English language classes at higher technical educational institution, formation of competencies.
Постановка проблеми у загальному вигляді. Інтеграція української держави до світового співтовариства, орієнтація на загальноєвропейські гуманістичні традиції, підтримка й захист національних цінностей, долучення до полікультурних освітніх, економічних, мовних програм та проєктів вимагають підготовки фрахівців, здатних до ефрективної взаємодії як на рівні міжособистісного спілкування, так і в межах міждержавного співробітництва. У низці законодавчих документів («Національна стратегія розвитку освіти в Україні на 2012-2021 рр., Закони України «Про освіту» (2017), «Про вищу освіту» (2014 р.) тощо) виокремлено нові завдання та критерії фрахової підготовки фрахівців, серед яких пріоритетним $є$ формування у студентів фахових компетентностей, пріоритетною серед яких $є$ саме інформаційно-комунікативна.

У комунікативному процесі як процесі обміну думками визначаються статуси речей і суб'єктів комунікації. Відповідно, постають вимоги до володіння комунікативною компетентністю студентами 
закладів вищої технічної освіти як вагомої передумови їхньої професійної компетентності. Поряд із цим сучасне інформаційне суспільство вимагає від фрахівця XXI сторіччя ґрунтовного володіння іноземною мовою та досконалого оперування інформаційними технологіями. 3 огляду на це, важливим завданням вищої профресійної технічної освіти $€$ пошук ефективних засобів фрормування інформаційно-комунікативної компетентності майбутніх інженерів із метою забезпечення виконання ними професійних обов'язків та своєчасного вирішення різних професійних завдань.

Аналіз останніх досліджень і публікацій. Розвиткові компетентностей присвячено праці Н. Бібік, С. Бондар, І. Єрмакова, І. Зимньої, О. Овчарук, О. Пометун, Дж. Равена, С. Тищенко й інших. Низка досліджень присвячена проблемі фрормування комунікативної компетентності (М. Васильєва, Н. Волкова, І. Комарова, С. Ольховецький, Л. Паламар, Л. Петровська, В. Полторацька, В. Тернопільська та інші). Використанню інфрормаційних технологій в освітньому процесі закладів вищої технічної освіти присвячено наукові доробки О. Алексєєва, В. Бикова, М. Коротуна, С. Семерікова, Д. Требухова та інших. Роль інфрормаційних технологій на заняттях з англійської мови аналізують О. Дакалюк, Л. Ломакіна, Г. Сорокіна, Н. Тимощук та інші.

Інфрормаційно-комунікативну компетентність вивчають учені І. Водько, Т. Гурова, Л. Дзюба-Шпурик, А. Приходько, Г. Федорук та інші у таких аспектах, як: фоормування інформаційно-комунікативної компетентності вчителів фрізичного виховання та спорту (І. Водько), умови фрормування інфрормаційно-комунікативної компетентності викладачів сучасних технологій (Г. Федорук).

Виділення не вирішених раніше частин загальної проблеми. Варто відзначити, що ці інтенсивні різнопланові дослідження значною мірою не вирішують проблему формування інформаційно-комунікативної компетентності студентів закладів вищої технічної освіти, поза увагою науковців залишаються питання її формування на заняттях 3 англійської мови.

Мета статті полягає в обґрунтуванні теорії та практики фрормування інфрормаційно-комунікативної компетентності майбутніх інженерів на заняттях 3 англійської мови в закладах вищої технічної освіти.

Формулювання цілей статті. Реалізація мети потребує вирішення таких завдань: 1) визначити сутність інфрормаційної, комунікативної та інфрормаційно-комунікативної компетентності майбутніх інженерів; 2) проаналізувати теорію і практику форомування інфрормаційно-комунікативної компетентності майбутніх інженерів машинобудівної галузі на заняттях 3 англійської мови.

У процесі виконання завдань використано методи аналізу, синтезу, узагальнення, систематизації, вивчення нормативних документів.
Виклад основного матеріалу дослідження. Інформаційно-комунікативна компетентність фрахівця О. Спіріним розглядається як підтверджена здатність особистості використовувати на практиці інформаційно-комунікаційні технології для задоволення власних потреб і розв'язування суспільно значущих, зокрема професійних, завдань у певній предметній галузі [8]. А. Зав'ялов зазначає, що сорормована інфрормаційно-комунікативна компетентність особистості забезпечує їй можливість орієнтуватися в динамічному соціокультурному просторі різних культур, $з$ одного боку, а з іншого - допомагає збільшувати обсяг інфрормації і знань, поступово будувати певний стиль комунікації, що вирізняється підвищеною соціальною активністю, а також новими принципами взаємодії в інфрормаційному суспільстві [3].

Поняття «інорормаційно-комунікативна компетентність» визначаємо як інтегральне від понять «інформаційна компетентність» і «комунікативна компетентність». У процесі наукового пошуку (М. Васильєва, Н. Волкова, І. Комарова, Л. Паламар та інші) комунікативну компетентність майбутнього інженера розглядаємо як здатність фрахівця встановлювати інтерактивну взаємодію у процесі професійної інженерної діяльності, використовуючи вербальні й невербальні засоби спілкування та створювати міжособистісний простір у процесі активної та ініціативної комунікації з іншими.

У контексті цього ми підтримуємо погляди H. Баловсяк, яка зазначає, що інформаційна компетентність включає три компоненти, такі як: інфрормаційна компонента (здатність ефективної роботи 3 повідомленнями у всіх фрормах їх представлення); комп'ютерна або комп'ютернотехнологічна компонента (здатність роботи з сучасними комп'ютерними засобами та програмним забезпеченням); процесуально-діяльнісна компонента (здатність застосовувати сучасні засоби інфрормаційних та комп'ютерних технологій роботи з інфрормаційними ресурсами та розв'язування різноманітних задач) [1].

3 огляду на окреслене, інформаційно-комунікативну компетентність майбутнього інженера будемо розуміти як інтегральну характеристику особистості, яка полягає у сорормованій здатності налагоджувати та здійснювати професійну комунікативну взаємодію з використанням вербальних та невербальних засобів комунікації, інфрормаційно-комунікаційних технологій задля вирішення профресійних завдань у технічній сорері та задля особистісного й професійного вдосконалення.

Значний потенціал у фрормуванні інфрормаційно-комунікативної компетентності відводимо заняттям 3 англійської мови. У контексті нашого дослідження вагомими є погляди Т. Пахомової, яка визначає англомовну комунікативну компетентність як здатність і готовність студентів 
здійснювати ефрективну комунікацію англійською мовою та включає: мовну (лінгвістичну) компетенцію, яка передбачає систему знань, умінь і навичок здійснювати англомовну комунікацію в типових ситуаціях навчальної, трудової та культурної сорер спілкування; соціокультурну компетенцію, яка включає фронові знання (сукупність відомостей про соціокультурні особливості народу, мова якого вивчається, та про стандарти комунікативної поведінки, прийняті в цій культурній спільноті); професійну компетенцію, яка передбачає знання фахової термінологічної лексики, а також навички роботи з матеріалом [5, с. 60].

Зупинимося на аналізі практики фрормування інфрормаційно-комунікативної компетентності у студентів галузі знань 13 Механічна інженерія, спеціальності 133 Галузеве машинобудування.

Метою вивчення курсу «Практичний курс іншомовного наукового спілкування» $€$ фрормування в майбутніх інженерів професійно орієнтованих іншомовних мовленнєвих компетенцій в аудіюванні, говорінні, читанні, письмі та перекладі/ медіації [2].

Відповідно до Стандарту Вищої освіти, зміст формування інфрормаційно-комунікативної компетентності майбутніх інженерів на заняттях 3 англійської мови має бути спрямований на досягнення таких програмових результатів, як: ПР03 - розуміти та пояснювати англійською мовою екологічно небезпечні та шкідливі фрактори профресійної діяльності та коригувати ії зміст із метою попередження негативного впливу на навколишнє середовище; ПР04 - володіти засобами сучасних інорормаційних та комунікаційних технологій в обсязі, достатньому для навчання та професійної англомовної діяльності; ПР05 - пояснювати англійською мовою свої рішення і підґрунтя їх прийняття фрахівцям і нефахівцям у ясній і однозначній формі; ПР10 пояснювати англійською мовою вплив конструктивних параметрів елементів машинобудівної техніки на її технічні характеристики; ПР13 - описувати англійською мовою будову металів та неметалів та знати методи модифікації їх властивостей; призначати оптимальні матеріали для елементів та систем машинобудівної техніки з урахуванням їхньої структури, фрізичних, механічних, хімічних та експлуатаційних властивостей, а також економічних фракторів; ПР15 - описувати англійською мовою експериментальні методи дослідження структурних, фрізико-механічних і технологічних властивостей матеріалів та конструкцій; ПР16 мати навички розроблення технологічних процесів, в тому числі із застосуванням автоматизованого комп'ютерного проектування виробництва конструктивних елементів та систем машинобудівної техніки; ПР23 - оцінювати англійською мовою економічну ефрективність виробництва елементів та систем машинобудівної техніки [9].
Тому 3 метою фрормування інфрормаційнокомунікативної компетентності та забезпечення сорормованості кінцевих програмових результатів навчання майбутніх інженерів на заняттях 3 англійської мови фрормуємо лінгвістичні здатності через засвоєння широкого діапазону словникового запасу лексики за фрахом; граматичні англомовні знання професійних термінів; мовленнєві вміння 3 аудіювання (вилучати специфрічну інфрормацію з аудіоповідомлень; розуміти складну інфрормацію, таку як оперативні інструкції, специорікації на знайомі продукти, пропозиції послуг тощо; розуміти аудіоповідомлення на теми, які здебільшого зустрічаються в академічному та професійному житті, та визначати погляди й ставлення мовця), уміння англомовного говоріння (виступати 3 непідготовленими англомовними повідомленнями на теми машинобудівної проблематики, складати професійно орієнтовані діалоги, обмінюватися думками та інформацією на складні теми машинобудівної галузі, розуміти монологічне і діалогічне мовлення у рамках різних сорер і професійно орієнтованих ситуацій спілкування), англомовного читання (розуміти складні автентичні тексти з машинобудівної галузі, визначати позиції і погляди в автентичних текстах, пов'язаних зі спеціальністю; розпізнавати широкий діапазон термінології та скорочень з галузі), англомовного перекладу (здатність продукувати на письмі відповідні фрункції та поняття машинобудівної галузі, володіння широким діапазоном галузевої термінології) та англомовного письма (здійснювати підготовку анотацій до автентичних галузевих текстів; формулювати власні резюме, здійснювати підготовку проблемно-тематичних повідомлень, готувати і продукувати ділову та професійну кореспонденцію тощо) [2, с. 122-123].

Варто наголосити, що кожна 3 тем курсу «Практичний курс іншомовного наукового спілкування» містить значний потенціал у формуванні інформаційно-комунікативної компетентності. Наприклад, у процесі вивчення теми «Evaluation. Projects», здійснюючи оцінку реалізації різноманітних проєктів, майбутні інженери, використовуючи такі інформаційні технології, як мультимедійні програми, у своєму режимі та відповідно до своїх потреб через одночасність візуального та слухового сприйняття, синтезу та синхронізації вербалізованих та невербалізованих знань, синхронізації та інтеграції часово-просторових та візуально-просторових джерел навчальної інорормації аналізують та вдосконалюють профресійну англомовну лексику. На наш погляд, використання власно підготовлених англомовних мультимедійних презентацій забезпечує удосконалення монологічного мовлення студентів із машинобудівної галузі. У процесі свого виступу майбутні інженери оперують англомовними професійними термінами 
(mechanical engineering, gearbox, precaution, update, regenerative, combustion chamber та ін.), ілюструючи свою доповідь самостійно розробленими схемами.

Ефективним у фрормуванні інфрормаційно-комунікативної компетентності майбутніх інженерів $€$ використання методів, що мають на меті пошук та використання комплексу тематично організованих on-line автентичних матеріалів. Наприклад, у процесі вивчення теми «Agreements. Proposals» пропонуємо віднайти і здійснити аналіз «Експортна стратегія сектору машинобудування 2020 року» та визначити умови подальшого розвитку авіаційної промисловості в Україні. Або віднайти «Розвиток співпраці у сорері машинобудування», здійснити ії аналіз та провести обговорення основних напрямів відродження національного машинобудування в Україні тощо.

Формуванню інорормаційно-комунікативної компетентності студентів у процесі вивчення курсу «Практичний курс іншомовного наукового спілкування» сприяє й робота із професійно-орієнтованими пошуковими системами Metasearch Search Engine, Yahoo та RefSeek 3 метою пошуку цікавих матеріалів із машинобудівної галузі, а саме серед веб-сторінок (American Society of Mechanical Engineers, Technology Student Association, NCEES та ін.), енциклопедій (енциклопедія Half-Life тощо), журналів і газет (Government courier, The Journal of Engineering in Economic Development тощо).

Висновки. Отже, інформаційно-комунікативна компетентність студентів $€$ важливою складовою частиною їхньої профресійної компетентності. Формування інорормаційно-комунікативної компетентності на заняттях 3 англійської мови передбачає удосконалення в майбутніх інженерів машинобудування здатностей здійснювати пошук, відбір та інтерпретацію професійної інформації з галузі, її аналіз, продукування, поширення та відтворення у процесі англомовного профресійного спілкування. Майбутній інженер зі сфрормованою інфрормаційно-комунікативною компетентністю здатний ефективно використовувати інорормаційні технології, здійснювати пошук, аналіз та продукування різного виду інфрормації; має новий тип мислення.
Проведене дослідження не претендує на вичерпний розгляд проблеми. Подальшого вивчення потребують питання організації самостійної роботи з англійської мови з розвитку інформаційно-комунікативної компетентності майбутніх інженерів.

\section{БІБЛІОГРАФІЧНИЙ СПИСОК:}

1. Баловсяк Н. Структура та зміст інорормаційної компетентності майбутнього спеціаліста. Науковий часопис Національного педагогічного університету імені М.П. Драгоманова. 2006. № 11. URL: http:// enpuir.npu.edu.ua/bitstream/123456789/888/1/30.pdf

2. Галацин К.О., Хом'як А.П. Інтерактивні технології формування комунікативної культури майбутніх фахівців на заняттях з англійської мови : навч. посіб. Луцьк, 2019. 128 с.

3. ЗавьяловА.Н. Формированиеынорормационной компетентности студентов в области компьютерных технологий: автореф. дис. ... канд. пед. наук : 13.00.01 «Общая педагогика, история педагогики и образования»; Тюменский государственный университет. Тюмень, 2005. 17 с.

4. Педагогічна майстерність: підручник / І.А. Зязюн, Л.В. Крамущенко, І.Ф. Кривонос та ін. ; за ред. І. А. Зязюна. Київ, 1997. 349 с.

5. Пахомова Т.О., Сенченко Я.С. Формування англомовної комунікативної компетентності студентів-срілологів в умовах лінгвосоціокультурного підходу. Вісник Дніпропетровського університету імені Альфреда Нобеля. Серія «Педагогіка і психологія». 2013. № 1. С. 59-64.

6. Рапацевич Е.С. Педагогика: Большая современная энциклопедия. Минск, 2005. 720 с.

7. Семотюк О. Сучасний словник іншомовних слів. 2011. 688 с.

8. Спірін О. Інформаційно-комунікаційні та інсрормативні компетентності як компоненти системи профресійно-спеціалізованих компетентностей вчителя інформатики. Інфрормаційні технології і засоби навчання. 2009. № 5(13). 16 c. URL: http:// eprints.zu.edu.ua/3733/2/09somtio.htm

9. Стандарт Вищої освіти України для першого (бакалаврського) рівня вищої освіти галузі знань 13 «Механічна інженерія», спеціальності 133 «Галузеве машинобудування» : Наказ Міністерства освіти і науки України 16.06.2020 р. № 806: URL: https://mon.gov.ua/ storage/app/media/vyshcha/standarty/2020/06/17/133\%20 Haluzeve\%20mashynobuduvannya\%20bakalavr.pdf 